\title{
Physical, Barrier and Antioxidant Properties of Pea Starch-Guar Gum Biocomposite Edible Films by Incorporation of Natural Plant Extracts
}

Bahareh Saberi, Quan V. Vuong, Suwimol Chockchaisawasdee, John B. Golding, Christopher J. Scarlett, Costas E. Stathopoulos

This is the authors' final version of this article. The final publication is available at Springer via http://dx.doi.org/10.1007/s11947-017-1995-z 
1 Physical, Barrier and Antioxidant Properties of Pea Starch-Guar Gum Biocomposite

2 Edible Films by Incorporation of Natural Plant Extracts

3 Bahareh Saberi ${ }^{\mathrm{a}^{*}}$, Quan V. Vuong ${ }^{\mathrm{a}}$, Suwimol Chockchaisawasdee ${ }^{\mathrm{a}, \mathrm{c}}$, John B. Golding ${ }^{\mathrm{b}}$,

4 Christopher J. Scarlett ${ }^{\mathrm{a}}$, Costas E. Stathopoulos ${ }^{\mathrm{c}}$

5

6 a School of Environmental and Life Sciences, University of Newcastle, Ourimbah, NSW 2258,

7 Australia

$8 \quad$ b NSW Department of Primary Industries, Ourimbah, NSW 2258, Australia

$9{ }^{\mathrm{c}}$ Division of Food and Drink, School of Science, Engineering and Technology, University of 10 Abertay, Dundee DD1 1HG, UK

*Correspondence to:

13 Bahareh Saberi

14 School of Environmental and Life Sciences, Faculty of Science and Information Technology, 15 University of Newcastle, Brush Road, Ourimbah, NSW 2258, Australia. 


\section{Abstract}

Active food packaging based on pea starch and guar gum (PSGG) films containing natural antioxidants (NAs) was developed. Four kinds of NAs (epigallocatechin gallate (EGCG), blueberry ash (BBA) fruit extract, macadamia (MAC) peel extract, and banana (BAN) peel extract) were added into PSGG-based films as antioxidant additive. The effects of these compounds at different amounts on physical and antioxidant characteristics of PSGG film were investigated. The antioxidant activity was calculated with three analytical assays: DPPH radical scavenging ability assay, cupric reducing antioxidant capacity (CUPRAC) and ferric reducing activity power (FRAP). EGCG-PSGG films showed higher antioxidant activity, followed by BBA-PSGG, MAC-PSGG and BAN-PSGG films, at all concentrations $(0.75-3 \mathrm{mg} / \mathrm{mL})$ and with all procedures tested. Additionally, the antioxidant activity of films showed a concentration dependency. The results revealed that addition of NAs made the PSGG film darker and less transparent. However, the moisture barrier was significantly improved when NAs were incorporated into the film. The FTIR spectra were examined to determine the interactions between polymers and NAs. The results suggested that incorporation of EGCG, BBA, MAC, and BAN into PSGG film have great potential for use as active food packaging for food preservation.

Keywords Pea starch . Guar gum . Active edible film . Natural extracts . Antioxidant activity 
53 Oxidation is the major cause of food degradation which can reduce the shelf life of food (Miller and Krochta 1997), decrease nutritional quality, increase toxicity, develop off-odor, and alter texture and color (Perazzo et al. 2014). The direct incorporation of antioxidants in food products is limited due to the high probability for rapid depletion of the antioxidants as well as the very high initial concentrations required to prevent this oxidation (Finley and Given 1986). Edible films and coatings can be developed as oxygen barrier layer and carrier for antioxidant delivery to prevent oxidative damage (Moreno et al. 2015). The increased attention on food safety and consumer health has prompted researchers to examine and develop functional ingredients from natural resources such as antimicrobial enzymes, essential oils, bacteriocins and phenolic compounds, rather than synthetically manufactured ingredients (Ramos et al. 2012; Vodnar 2012). Active packaging aims to combine active ingredients including nutrient supplementation, antimicrobial, and antioxidant agents into packaging materials to preserve food quality, safety and shelf life (Coma 2008; Gutiérrez et al. 2009; Vermeiren et al. 1999; Wang et al. 2015b). The addition of phenolic compounds and extracts in active packaging not only allows the phenolics to prevent oxidation in the food, but it can also increase their direct human consumption to improve human health (Komes et al. 2010; Sun et al. 2014).

Many polyphenols including flavonoids and proanthocyanidins are derived from vegetables and fruits and are considered sources of bioactive compounds (Apak et al. 2007). These compounds are widely consumed in the human diet where their effective antioxidant characteristics have positive health advantages including the inhibition of cancer, cardiovascular diseases, obesities and diabetes (Vuong et al. 2014). 
Catechins are the main tea polyphenols in green tea extract mostly such as epicatechin (EC), epigallocatechin (EGC), epicatechin gallate (ECG), epigallocatechin gallate (EGCG) (Yu et al. 2015). EGCG is an active polyphenolic catechin and comprises around 59\% of the total catechins from the leaves of the green tea (Steinmann et al. 2013). To the best of our knowledge, the effect of EGCG on antioxidant and physical properties of PSGG edible film has not yet been investigated.

Blueberry ash (Elaeocarpus reticulatus $\mathrm{Sm}$.) is a plant that belongs to Elaeocarpaceae family grown in rainforest and coastal scrub along the east coast of Australia (Rickard 2011). There is limited information on phytochemical and antioxidant characteristics of blueberry ash fruits. In this study, the potential application of blueberry ash fruit extract as an antioxidant compound to PSGG edible film was investigated.

The macadamia is recognized as an evergreen, native Australian tree with two more common species, the Macadamia integrifolia (smooth shelled) and the Macadamia tetraphylla (rough shelled) (Munro and Garg 2008). The skin/husk of the macadamia has been suggested to have plenty of phenolic compounds (Alasalvar and Shahidi 2009; Dailey and Vuong 2016). Therefore, active biodegradable packaging can be developed by incorporation of phenolic compounds derived from macadamia skin.

Banana peel accounts for approximately $40 \%$ of total weight of the fresh fruit (Anhwange 2008). The peel of banana as a natural source of antioxidants and phytochemical content specially catecholamines (Kanazawa and Sakakibara 2000), gallocatechin (Someya et al. 2002), phenolic (Baskar et al. 2011; del Mar Verde Méndez et al. 2003; Fatemeh et al. 2012; Nguyen et al. 2003), dopamine (Kanazawa and Sakakibara 2000), lutein (Davey et al. 2006), as well as carotenoid compounds (Davey et al. 2006; van den Berg et al. 2000) has been taken 
into account. So far, there is no report on the impact of the incorporation of banana peel extract to the pea starch-guar gum edible films.

Therefore, this study was conducted to analyse the effect of various natural plant extracts on antioxidant properties of pea starch-guar gum films. In addition, the effect of these extracts was examined on the barrier, physical, and optical characteristics of pea starch-guar gum edible film.

\section{Materials and Methods}

\section{Materials}

In all experiments Canadian non-GMO yellow pea starch (suppliedby Yantai Shuangta Food Co., Jinling Town, China) with $13.2 \%$ moisture, $0.2 \%$ protein, $0.5 \%$ fat, $0.3 \%$ ash, and $36.25 \%$ amylose was used. Guar gum (E-412) was provided by The Melbourne Food Ingredient Depot, Brunswick East, Melbourne, Australia. All other chemicals were purchased from SigmaAldrich Pty Ltd, Castle Hill, NSW, Australia. Commercial epigallocatechin gallate Teavigo ${ }^{\mathrm{TM}}$ EGCG was obtained from RejuvaCare, Sydney, NSW, Australia. It was in the form of dry powder stored at $5-8{ }^{\circ} \mathrm{C}$ until needed.

\section{Preparation of Extracts}

The method described by Dailey and Vuong (2015) was used for extraction from macadamia skin (Macadamia tetraphylla). In short, the extraction process was performed on the dried and ground skin of macadamia harvested in the Central Coast region, New South Wales, Australia (latitude of $33.4^{\circ} \mathrm{S}$, longitude of $151.4^{\circ} \mathrm{E}$ ). The extraction process was performed in an ultrasonic bath (Soniclean, 220 V, $50 \mathrm{~Hz}$ and 250 W, Soniclean Pty Ltd., The barton, Australia) with pre-set conditions for temperature of $40{ }^{\circ} \mathrm{C}$, time of $35 \mathrm{~min}$, power of $200 \mathrm{~W}$, sample to solvent ratio of 5:100 g/mL and a mixture of acetone: water $(1: 1 \mathrm{v} / \mathrm{v})$. 
121 The extraction of phenols from blueberry fruits was carried out as described by Saberi et al.

122 (2017). Blueberry ash (Elaeocarpus reticulatus Sm.) fruits were collected in August 2015 from the Central Coast region of New South Wales (NSW), Australia. The extraction solvent (50\% acetone) at a solvent-to-sample ratio of $100: 1 \mathrm{~mL} / \mathrm{g}$ of dried sample was applied to extract bioactive compounds from blueberry ash fruits using ultrasound assisted extraction (UAE). The extraction process was performed in an ultrasonic bath with pre-set conditions for temperature of $35^{\circ} \mathrm{C}$, time of $30 \mathrm{~min}$ and power of $150 \mathrm{~W}$, followed by agitation for $3 \mathrm{~s}$ once every 5 min using a Vortex. The extracts were immediately cooled on ice to room temperature, after the ultrasonic extraction was completed. The extract was then filtered using a $5 \mathrm{~mL}$ syringe fitted with a $0.45 \mu \mathrm{m}$ cellulose syringe filter (Phenomenex Australia Pty. Ltd., Lane Cove, Australia). The filtered extract was kept at $4{ }^{\circ} \mathrm{C}$ before further analysis.

The extraction of phenols from banana peel was carried out according to Vu et al. (2016). Briefly, the ripe bananas (Musa acuminata cavendish) were purchased from a local market, Central Coast, NSW, Australia. Peels from ripe mature banana fruit were manually separated and cut into pieces $(1 \times 2 \mathrm{~cm})$. The extraction process was conducted at UAE temperature of $30{ }^{\circ} \mathrm{C}$, UAE time of $5 \mathrm{~min}$, UAE power of $60 \%(150 \mathrm{~W})$, sample to solvent ratio of 8:100 g/mL and acetone concentration of $60 \%$.

\section{Film Preparation}

The film-forming solution was made by dissolving optimized amounts of pea starch $(2.5 \mathrm{~g})$, guar gum $(0.3 \mathrm{~g})$ and $25 \% \mathrm{w} / \mathrm{w}$ glycerol based on the dry film matter in $100 \mathrm{~mL}$ degassed deionized water with gentle heating (about $40{ }^{\circ} \mathrm{C}$ ) and magnetic stirring for about $1 \mathrm{~h}$. In another study, we optimized the film ingredients by using Box-Behnken response surface design (BBD) (Saberi et al. 2016b). After gelatinization at $90{ }^{\circ} \mathrm{C}$ for $20 \mathrm{~min}$, the film solution was cooled to room temperature with mild magnetic stirring for $1 \mathrm{~h}$ to decrease air bubbles. 
Plant extracts at defined concentrations $(0.75 \mathrm{mg} / \mathrm{mL}, 1.5 \mathrm{mg} / \mathrm{L}, 2.25 \mathrm{mg} / \mathrm{mL}$, and $3 \mathrm{mg} / \mathrm{mL})$ were added. According to preliminary experiments, PSGG film with active compounds lower than $0.75 \mathrm{mg} / \mathrm{mL}$ possessed a weak antibacterial activity and therefore higher levels of extracts were tested in this study (Saberi et al. 2017). Filmogenic suspensions (20 g) were cast onto Petri dishes $\left(10 \mathrm{~cm}\right.$ in diameter) and dried at $40{ }^{\circ} \mathrm{C}$ in an oven until reaching constant weight (about $24 \mathrm{~h}$ ). Films were peeled-off carefully from Petri dishes and conditioned at $25{ }^{\circ} \mathrm{C}, 65 \%$ relative humidity $(\mathrm{RH})$ for $72 \mathrm{~h}$ prior to further tests.

\section{Moisture Content}

Moisture content (MC) of the films was calculated gravimetrically by using a ventilated oven at $105 \pm 1{ }^{\circ} \mathrm{C}$ for $24 \mathrm{~h}$ until constant weight was reached. All the tests were performed in triplicate, and the means were reported. Moisture content was determined by the following equation:

$\operatorname{MC}(\%)=\frac{M_{w}-M_{d}}{M_{w}} \times 100$

where $M_{w}$ is the weight of the films conditioned in $65 \% \mathrm{RH}$ to moisture equilibrium and $\mathrm{M}_{d}$ is the dry weight of the films (Wang et al. 2015b).

Water Solubility (WS), Gel Fraction (GF) and Swelling Degree (SD)

Film samples in $40 \mathrm{~mm} \times 15 \mathrm{~mm}$ pieces conditioned in $65 \% \mathrm{RH}$ to moisture equilibrium was weighed to the nearest $0.1 \mathrm{mg}$, and the amount was referred as $\mathrm{M}_{\mathrm{w}}$. The film specimens were submerged into $50 \mathrm{~mL}$ of distilled water in a $50 \mathrm{~mL}$-beaker with gentle agitation at room temperature for $24 \mathrm{~h}$. The film was filtered under vacuum through $\mathrm{MN}-640 \mathrm{~m}$ filter papers (Macherey-Nagel, Germany) and weighed in an analytical balance with a precision of $0.1 \mathrm{mg}$ (the amount was referred to as $\mathrm{W}_{\mathrm{w}}$ ), then dried at $110{ }^{\circ} \mathrm{C}$ in a vacuum oven to constant weight 
(the amount was referred to as $\mathrm{W}_{\mathrm{d}}$ ). The following equations were applied to measure water

169 WS $(\%)=\frac{M_{w}(1-M C)-W_{d}}{M_{w}(1-M C)} \times 100$

$170 \quad \mathrm{GF}(\%)=\frac{W_{d}}{M_{w}(1-M C)} \times 100$

$171 \quad \mathrm{SD}=\frac{W_{w}}{W_{d}}$

172 where $\mathrm{MC}$ is the moisture content of the film specimens conditioned in $65 \% \mathrm{RH}$. Three 173 replicates were performed and averaged for each sample.

Water Vapor Permeability

Water vapor permeability (WVP) of films was examined using the method explained by Sun et al. (2014) with some modifications. The films were sealed onto test cups half-filled with

177 anhydrous calcium chloride $\left(\mathrm{CaCl}_{2}\right)(0 \% \mathrm{RH})$ and then placed in a desiccator containing saturated $\mathrm{NaCl}$ solution $(75 \% \mathrm{RH})$ and kept at $25^{\circ} \mathrm{C}$. The test cups were weighed as a function of time until changes in the weight were recorded to the nearest $0.001 \mathrm{~g}$. Water vapor transmission rate (WVTR) was calculated by dividing the slope of straight line $(\mathrm{g} / \mathrm{m})$ obtained

181 from the weight gain as a function of time data, with film surface area, and WVP was measured 182 as follows:

where $\Delta \mathrm{P}$ is the water vapor pressure difference between the two sides of the film (Pa). WVP was measured for three replicated samples for each type of films. 

to determine films transparency (Saberi et al. 2016c). The films were cut into rectangular shapes $(5 \mathrm{~mm} \times 40 \mathrm{~mm})$ and placed inside the spectrophotometer cell and the film transparency was taken at $560 \mathrm{~nm}$.

The color of each film was measured with a Minolta colorimeter (CR-300 series, Radiometric instruments Operations, Osaka, Japan). The lightness (' $L$ ') and chromaticity parameters ' $a$ ' (red-green) and ' $b$ ' (yellow-blue) were analysed, as well as the total color difference $(\Delta \mathrm{E})$ of samples were calculated (Saberi et al. 2016c):

The $L^{*}, a^{*}$ and $b^{*}$ values were the color of a white color plate used as a standard for calibration and as a background for color measurements $\left(L^{*}=97.27, a^{*}=-3.52\right.$, and $\left.b^{*}=5.36\right)$ and ' $L$ ', ' $a$ ', and ' $b$ ' are the color parameter values of the sample. The measurements were repeated six times for each film.

The method described by Thakur et al. (2016) was applied to study IR spectra of the films using an infrared spectrometer (FTIR) (Thermo Fisher Scientific Inc., Nicolet iS10, USA). The spectrums were obtained at the range of between 450 and $4000 \mathrm{~cm}^{-1}$, using 40 scans at a resolution of $4 \mathrm{~cm}^{-1}$.

Each film sample $(25 \mathrm{mg})$ was dissolved in $5 \mathrm{~mL}$ of distilled water for $24 \mathrm{~h}$. The total phenolic content (TPC) was determined using Folin-Ciocalteu reagent, as described by Dailey and Vuong (2015). One $\mathrm{mL}$ of film extract was added to $5 \mathrm{~mL}$ of $10 \%$ (v/v) Folin-Ciocalteu reagent 
and then $4 \mathrm{~mL}$ of $7.5 \%(\mathrm{w} / \mathrm{v}) \mathrm{Na}_{2} \mathrm{CO}_{3}$ was added. The final solution was incubated in the dark at room temperature for $1 \mathrm{~h}$ and the absorbance was measured at $760 \mathrm{~nm}$. Gallic acid was used for plotting standard curve and the results were then reported in milligrams of gallic acid equivalents per gram of sample (mg GAE/g).

214 Total flavonoid content (TFC) was measured by mixing $0.5 \mathrm{~mL}$ of film extract solution with 2 $215 \mathrm{~mL}$ of distilled water and $0.15 \mathrm{~mL}$ of $5 \%(\mathrm{w} / \mathrm{v}) \mathrm{NaNO}_{2}$ and leaving at room temperature for 6 min. Afterwards, $0.15 \mathrm{~mL}$ of $10 \%(\mathrm{w} / \mathrm{v}) \mathrm{AlCl}_{3}$ was mixed and kept at room temperature (25 ${ }^{\circ} \mathrm{C}$ ) for another $6 \mathrm{~min}$. Finally, the final solution was prepared with addition of $2 \mathrm{~mL} 4 \%(\mathrm{w} / \mathrm{v})$ $\mathrm{NaOH}$ and $0.7 \mathrm{~mL}$ of distilled water and incubated at room temperature for $15 \mathrm{~min}$ and the absorbance was read at $510 \mathrm{~nm}$. The results were then expressed in milligrams of rutin equivalents per gram of sample (mg RUE/g) (Zhishen et al. 1999).

DPPH Radical Scavenging Activity

The antioxidant properties of the film samples was calculated using a DPPH (2, 2-diphenyl-1picrylhydrazyl) free radical scavenging assay following the technique of Papoutsis et al. (2016), and the results were specified as $\mathrm{mg}$ of trolox equivalents per gram of sample (mg $\mathrm{TE} / \mathrm{g})$.

The procedure defined by Apak et al. (2004) was used to measure CUPRAC with some adjustments. Film extract solution $(1.1 \mathrm{~mL})$ was added to working CUPRAC solution $(1 \mathrm{~mL}$ of $\mathrm{CuCl}_{2}, 1 \mathrm{~mL}$ of neocuproine and $1 \mathrm{~mL}$ of $\mathrm{NH}_{4} \mathrm{Ac}$ ) and after mixing well, the mixture was incubated at room temperature for $1.5 \mathrm{~h}$ before reading the absorbance at $450 \mathrm{~nm}$. The results were determined as milligram of trolox equivalents per gram of sample (mg TE/g). 
FRAP (Ferric reducing antioxidant power) was determined as explained by Vu et al. (2016). A standard curve was plotted using trolox and the results were calculated as milligram of trolox equivalents per gram of sample (mg TE/g).

Analysis of variance was performed and the results were separated using the Multiple Ranges Duncan's test $(P<0.05)$ using statistical software of Statistical Package for Social Science, SPSS (version 23, SPSS Inc., Chicago, IL, USA). All tests were carried out at least in triplicate.

\section{Results and Discussion}

Moisture Content

Moisture contents of the PSGG films with different ratios of active compounds are given in

Table 1. Among samples, films with EGCG performed the highest moisture content value from $20.3 \%$ to $17.5 \%$, which could be due to the more hydrophilic nature of the EGCG and the availability of its hydroxyl groups to bind water molecules (Kanmani and Rhim 2014). There was no significant difference between films with $0.75 \mathrm{mg} / \mathrm{mL}$ of EGCG and BBA. Increasing the ratio of EGCG and BBA to $1.5 \mathrm{mg} / \mathrm{mL}$ increased the moisture content value to $25.6 \%$ and $22.7 \%$, respectively, which is related to plasticization effect and disintegration of film matrix. This phenomenon increased the absorption of water molecules in polymer chains by hydrogen bonding (Jouki et al. 2014). Incorporation of EGCG and BBA at higher amounts into the PSGG films caused a significant decrease in the MC. Addition of MAC and BAN considerably $(P<$ 0.05) decreased moisture content of PSGG film. Lower moisture content of PSGG-MAC and PSGG-BAN films may be because of their lower hydrophilicity which can influence the capacity of the film to absorb water. Another possible reason for the reduction of MC could be 
owing to interactions between hydroxyl groups of polymers and hydroxyl groups of phenolic compounds, which result in the lack of interactions sites for water in glucosemonomers of polymers during drying (Talja et al. 2007). The difference of films in MC may have an association with the dissimilarity in chemical structure of constituent contained in extracts $(\mathrm{Li}$ et al. 2014). Reduction in moisture content was also noticed in the chitosan films with Lycium barbarum fruit extract (Wang et al. 2015b), green tea extract (Siripatrawan and Harte 2010), and tea polyphenols (Wang et al. 2013).

Water solubility of biodegradable films is an essential aspect since it can contribute to the water resistance of films, particularly in humid environment (Ashwar et al. 2015), and their biodegradability (Rotta et al. 2009). Water insolubility of films is also influential in specific circumstances in which it is necessary to improve the product integrity, moisture barrier characteristics and product shelf life (Tongdeesoontorn et al. 2011). The WS, GF, and SD of the PSGG films formulated with antioxidant compounds are summarized in Table 1. The results indicated that the reduction in WS of the PSGG films was significant $(P<0.05)$ when weight ratio of active agents was increased from $0.75 \mathrm{mg} / \mathrm{mL}$ to $3 \mathrm{mg} / \mathrm{mL}$. This might be a consequence of crosslinking of antioxidant compounds which can stabilize polymers structure and reduce its solubility in aqueous medium (Ashwar et al. 2015). The results were consistent with the film made from chitosan and Lycium barbarum fruit extract (Wang et al. 2015b), gelatin with green tea extract (Wu et al. 2013), and myofibrillar protein-based film formulated with grape seed and green tea polyphenols (Nie et al. 2015). Moreover, water solubility in EGCG- and BBA-incorporated films was moderately higher than those in MAC- and BANincorporated films. It might be due to the higher level of hydroxyl groups in EGCG and BBA molecules. All ingredients used in this study were completely soluble in water, but the water 
solubility of the obtained films was not $100 \%$, signifying gel formation. The interactions between polymers and antioxidant compounds are reasons for the gel formation. Consequently, the gel fraction increased as the concentration of natural extracts to PSGG film increased indicating the higher quantity of macromolecules engaged to produce gel (Wang et al. 2015b). Additionally, the data revealed that with the increasing amount of natural antioxidant agents, swelling degree (SD) of the films declined noticeably. The accessibility of the hydrophilic groups in the macromolecule networks to water reduced suggesting the more interaction between polymer chains and active compounds (Wang et al. 2015a). Cross-linking of compounds with PSGG diminished polymer relaxation and distribution of water into polymer, thereby decreased the SD of films (Yu et al. 2015). The degree of swelling of film is determined by drying temperature and the extent and the nature of intermolecular chain infarctions (Mayachiew and Devahastin 2010; Di Pierro et al. 2006). It should be noted that the molecular characteristics of phenolic compounds significantly contributed to the strength of film matrix (Moradi et al. 2012).

Water Vapor Permeability

Table 1 shows WVP of the PSGG films with different contents of antioxidant compounds. The data presented that the reduction in WVP of the PSGG films containing phenolic compounds was significant $(P<0.05)$ when their weight ratio to PSGG film was enhanced from 0.75 to 3 $\mathrm{mg} / \mathrm{mL}(P<0.05)$. With regard to the influence of phenolic compounds on water vapor transmission, incorporation of EGCG or BBA made the films more penetrable, which might be explained by more hydrophilic property of their phenolic compounds (Siripatrawan and Harte 2010), higher WVP for EGCG-PSGG and BBA-PSGG films at $1.5 \mathrm{mg} / \mathrm{mL}$ can be accounted by their higher water absorption ability. The high tendency of EGCG-PSGG and BBA-PSGG 
plasticization and consequent increase in WVP (Ashwar et al. 2015). Another reason may be due to the existence of EGCG or BBA bringing about less crystalline films and providing more free hydroxyl-hydrophilic position to water molecules and inducing high WVP (Rubilar et al. 2013). The increase in WVP of these films can be described by the similar hypothesis established for moisture content. The diminished WVP of PSGG-based films with higher amounts of active compounds probably originated from the interactions between PS and GG with phenolic compounds, which enhanced intermolecular interactions and resulted in decreased interchain space of the polymer, as can be demonstrated by reduction of the transmission of water vapor molecules in the film matrix (Wang et al. 2012). Reduction in WVP has been observed by addition of natural plant extracts to edible films (Cheng et al. 2015; Wang et al. 2015b; Wang et al. 2015a; Wang et al. 2012; Li et al. 2014).

Optical Properties

Color characteristics are imperative for film appearance concerning consumer acceptance and general appearance for the packed products (Wang et al. 2015a; Wang et al. 2015b). The color properties of PSGG films formulated with different natural antioxidants can be seen in Table 2. The incorporation of all natural phenolic compounds influenced the appearance of edible PSGG films in both color and transparency. Edible PSGG films with filled EGCG or BBA became darker red-blueish as observed by the decreased $L$ and $b$, and increased $a$ values when the weight ratio of these compounds in the film enhanced (Table 2). The PSGG films formulated with MAC or BAN demonstrated $a$ light yellowish tint, which is an indication of increased $b$ value. The native color of the edible PSGG films changed because the incorporation of different combinations could structurally attached to the film matrix (Moradi et al. 2012). The color variation was closely associated with the quantity of phenolic acids and flavonoids contained in the various compounds (Corrales et al. 2009). $\Delta \mathrm{E}$, as a parameter of the total color 
changes of films, enhanced with increasing the amount of natural compounds, resulting in more colored films. Similar trends in film color have been also evidenced in chitosan (Moradi et al. 2012; Wang et al. 2015b), hydroxypropyl methylcellulose (HPMC) (Chana-Thaworn et al. 2011), apple puree (Du et al. 2011), soy protein (Sivarooban et al. 2008) and pea starch (Corrales et al. 2009) edible films.

Incorporating all active compounds into the PSGG edible film led to a reduction in its transparency. The decline in transparency could probably be owing to the light scattering from the hindering of light transmission of the edible PSGG films and phenolic compounds added into the edible PSGG films (Chana-Thaworn et al. 2011).

\section{Fourier-Transform Infrared (FTIR) Spectroscopy}

Since changes were observed in the physical properties of the films, complementary study at the molecular level was performed to scrutinize interaction between functional groups in the films. FTIR spectrums of PSGG films with different active compounds at weight ratio of 3 $\mathrm{mg} / \mathrm{ml}$ are shown in Fig. 1. The chemical associations among different compounds can be revealed by variations in the characteristic spectra peaks (Xu et al. 2005). As it can be seen, the major appearances of the FTIR spectra of PSGG film did not alter by incorporation of active compounds, so representing no main changes of the polymers backbone, no phase separation and thus the miscibility and compatibility of employed compounds with PSGG films (Wang et al. 2012). The peak linked to the stretching vibration of free, inter- and intramolecular bound hydroxyl groups between $3000 \mathrm{~cm}^{-1}$ to $3600 \mathrm{~cm}^{-1}$ (Zhang and Han 2006), turned into wider and sharper when PSGG film formulated with natural extracts, which revealed that polyphenols in these ingredients comprised a number of $\mathrm{O}-\mathrm{H}$ and $\mathrm{C}=\mathrm{O}$ bands to create the intramolecular and intermolecular hydrogen bond (cross-links) ( $\mathrm{Li}$ et al. 2014). Moreover, the intensity of C-O and C-C bands at $1000-1300 \mathrm{~cm}^{-1}$ was found to increase by addition of these extracts. 
351 Simultaneously, the sharp peak at 2700-3000 $\mathrm{cm}^{-1}$ associated with C-H stretching (Park et al.

352 2000), became more obvious with extracts added to film. Furthermore, the peaks between 1500 $\mathrm{cm}^{-1}$ and $1675 \mathrm{~cm}^{-1}$, corresponding to the stretching vibration of $\mathrm{C}=\mathrm{O}$ bands and bending vibration of $\mathrm{C}-\mathrm{O}-\mathrm{H}$ bands were more recognized in films with extracts, because these bands can simply make the intermolecular hydrogen bond with $\mathrm{O}-\mathrm{H}$ bands in polyphenol compounds (Siripatrawan and Harte 2010). The results of FTIR showed that addition of EGCG, BBA, MAC and BAN into PSGG film brought about interactions happening between polymers and active compounds. These intramolecular and intermolecular hydrogen bonds decrease the free hydrogen, which can constitute hydrophilic bonding with water leading to improved water barrier characteristics (Gómez-Guillén et al. 2007; Curcio et al. 2009).

Total Phenolic Content (TPC) and Total Flavonoids (TF)

The most antioxidant active metabolites from plants are considered phenolic and polyphenolic compounds (Bors et al. 2001). There is a significant association between the content of phenolic compounds and antioxidant capacity (Pan et al. 2008), because these combinations have the efficiency to make available hydrogen or electrons beyond their capability to scavenge free radicals and protect against oxidative process (Genskowsky et al. 2015). Total phenol (TPC) and total flavonoid (TFC) content of PSGG edible films containing different extracts was shown in Fig. 2. These factors can be applied as influential signs of the antioxidant capacity for any produce utilized as a natural source of antioxidants in functional foods (Viuda-Martos et al. 2011). Pure PSGG films did not show the existence of phenolic and flavonoid compounds (Fig. 2). The results exhibited that TPC and TFC in the PSGG films considerably was improved $(P<0.05)$ with increasing concentration of compounds (Fig. 2). The EGCG-incorporated PSGG film had the highest TPC and TFC compared with other films, while the lowest values were observed in films incorporated with $0.75 \mathrm{mg} / \mathrm{mL}$ of banana peel extract. 
The antioxidant capacity of the films has been determined as a percentage of free radicalscavenging capacity (DPPH), cupric reducing antioxidant capacity (CUPRAC) and ferric reducing antioxidant power (FRAP) in Table 3. More than one method is essential to calculate the antioxidant capacity of plant material extracts in vitro (Pérez-Jiménez et al. 2008), because of the differences in their ability to produce free radicals, the mechanism to determine the end point of the prevention reaction, and the affinity towards the various reducing molecules in the sample (Roginsky and Lissi 2005). Film without any compound did not show a free radicalscavenging, cupric and ferric reducing antioxidant activity. The presence of natural extracts into PSGG films increased their antioxidant activities in comparison to the PSGG films and this increase was determined by the concentration applied. Additionally, the results displayed that PSGG-EGCG, followed by PSGG-BBA, PSGG-MAC and PSGG-BAN film, comprises more phenolic to reduce free radicals and to cause more stable products. Phenolic compounds contain one or more aromatic rings bearing hydroxyl groups and are consequently capable to quench free radicals by developing resonance-stabilized phenoxyl radicals (Dudonné et al. 2009). Though, it should be taken into account that the antioxidant properties of natural extracts is not only due to phenolic compounds. Other components including ascorbates, reducing carbohydrates, tocopherols, carotenoids, terpenes, and pigments might give rise to antioxidant capacity (Babbar et al. 2011). In this study close relationship between TPC or TFC and antioxidant capacity (DPPH, CUPRAC and FRAP values) of PSGG films incorporated with various extracts was achieved and the results are illustrated in Table 4. This table shows the correlation of TPC and TFC with antioxidant properties of films formulated with natural compounds measured by DPPH, FRAP and CUPRAC. The higher value shows that the antioxidant activity of film is as a result of phenolic and flavonoid compounds in the extract. 


\section{Conclusion}

400 Active packaging films based on pea starch and guar gum formulated with antioxidants

401

402

403

404

405

406

407

408

409

410

411

412

413

414

415 compounds were effectively developed. The physical, optical and barrier characteristics of the PSGG films were mostly dependant on incorporated phenolic compounds. After incorporating active compounds into PSGG film, MC, WS, SD, WVP, and transparency of the films were significantly reduced. Results obtained from FTIR analysis exhibited that the modifications in the physical properties of films were nearly related to the interactions of polymers with antioxidant substances. The antioxidant activity of the PSGG film was noticeably enhanced after addition of natural compounds, which indicated the great potential of these films as active food packaging. Further studies should be taken into account regarding the use of these active packaging materials in vitro to determine the migration of phenolic compounds from the films and their effects on extending shelf-life during storage time.

\section{Acknowledgement}

This study was funded by the University of Newcastle, NSW Australia. The authors are thankful to Ms. Hang T. Vu and Ms. Adriana Dailey for providing us with banana peel extract and macadamia skin extracts.

\section{Conflict of Interest}

The authors declare no conflict of interest.

\section{References}

Abdollahi, M., Rezaei, M., \& Farzi, G. (2012). Improvement of active chitosan film properties with rosemary essential oil for food packaging. International Journal of Food Science \& Technology, 47(4), 847-853.

Alasalvar, C., \& Shahidi, F. (2009). Natural antioxidants in tree nuts. European Journal of Lipid Science and Technology, 111(11), 1056-1062, doi:10.1002/ejlt.200900098.

Anhwange, B. A. (2008). Chemical Composition of Musa sapientum (Banana) Peels. Journal of Food Technology, 6, 263-266. 
Apak, R., Guclu, K., Demirata, B., Ozyurek, M., Celik, S. E., Bektasoglu, B., et al. (2007). Comparative evaluation of various total antioxidant capacity assays applied to phenolic compounds with the CUPRAC assay. Molecules, 12(7), 1496-1547.

Apak, R., Güçlü, K., Özyürek, M., \& Karademir, S. E. (2004). Novel total antioxidant capacity index for dietary polyphenols and vitamins $\mathrm{C}$ and $\mathrm{E}$, using their cupric ion reducing capability in the presence of neocuproine: CUPRAC method. Journal of Agricultural and Food Chemistry, 52(26), 7970-7981.

Ashwar, B. A., Shah, A., Gani, A., Shah, U., Gani, A., Wani, I. A., et al. (2015). Rice starch active packaging films loaded with antioxidants-development and characterization. Starch-Stärke, 67(3-4), 294-302.

Babbar, N., Oberoi, H. S., Uppal, D. S., \& Patil, R. T. (2011). Total phenolic content and antioxidant capacity of extracts obtained from six important fruit residues. Food Research International, 44(1), 391-396.

Baskar, R., Shrisakthi, S., Sathyapriya, B., Shyampriya, R., R., N., \& Poongodi, P. (2011). Antioxidant potential of peel extracts of banana varieties (Musa sapientum). Food and Nutrition Sciences, 2, 1128-1133.

Bors, W., Michel, C., \& Stettmaier, K. (2001). Structure-activity relationships governing antioxidant capacities of plant polyphenols. Methods in Enzymology, 335, 166.

Chana-Thaworn, J., Chanthachum, S., \& Wittaya, T. (2011). Properties and antimicrobial activity of edible films incorporated with kiam wood (Cotyleobium lanceotatum) extract. LWT-Food Science and Technology, 44(1), 284-292.

Cheng, S.-Y., Wang, B.-J., \& Weng, Y.-M. (2015). Antioxidant and antimicrobial edible zein/chitosan composite films fabricated by incorporation of phenolic compounds and dicarboxylic acids. LWT-Food Science and Technology, 63(1), 115-121.

Coma, V. (2008). Bioactive packaging technologies for extended shelf life of meat-based products. Meat science, 78(1-2), 90-103.

Corrales, M., Han, J. H., \& Tauscher, B. (2009). Antimicrobial properties of grape seed extracts and their effectiveness after incorporation into pea starch films. International Journal of Food Science \& Technology, 44(2), 425-433.

Curcio, M., Puoci, F., Iemma, F., Parisi, O. I., Cirillo, G., Spizzirri, U. G., et al. (2009). Covalent insertion of antioxidant molecules on chitosan by a free radical grafting procedure. Journal of Agricultural and Food Chemistry, 57(13), 5933-5938.

Dailey, A., \& Vuong, Q. V. (2015). Optimisation of ultrasonic conditions as an advanced extraction technique for recovery of phenolic compounds and antioxidant activity from Macadamia (Macadamia tetraphylla) skin waste. Technologies, 3, 302-320.

Dailey, A., \& Vuong, Q. V. (2016). Optimum conditions for microwave assisted extraction for recovery of phenolic compounds and antioxidant capacity from Macadamia (Macadamia tetraphylla) skin waste using water. Processes, 4, 2.

Davey, M. W., Keulemans, J., \& Swennen, R. (2006). Methods for the efficient quantification of fruit provitamin A contents. Journal of Chromatography A, 1136(2), 176-184.

del Mar Verde Méndez, C., Forster, M. P., Rodríguez-Delgado, M. Á., Rodríguez-Rodríguez, E. M., \& Díaz Romero, C. (2003). Content of free phenolic compounds in bananas from Tenerife (Canary Islands) and Ecuador. European Food Research and Technology, 217(4), 287-290.

Delville, J., Joly, C., Dole, P., \& Bliard, C. (2002). Solid state photocrosslinked starch based films: a new family of homogeneous modified starches. Carbohydrate Polymers, 49(1), 71-81.

Di Pierro, P., Chico, B., Villalonga, R., Mariniello, L., Damiao, A. E., Masi, P., et al. (2006). Chitosan- whey protein edible films produced in the absence or presence of 
transglutaminase: analysis of their mechanical and barrier properties. Biomacromolecules, 7(3), 744-749.

Du, W. X., Olsen, C., Avena- Bustillos, R., Friedman, M., \& McHugh, T. (2011). Physical and antibacterial properties of edible films formulated with apple skin polyphenols. Journal of Food Science, 76(2), M149-M155.

Dudonné, S., Vitrac, X., Coutière, P., Woillez, M., \& Mérillon, J.-M. (2009). Comparative study of antioxidant properties and total phenolic content of 30 plant extracts of industrial interest using DPPH, ABTS, FRAP, SOD, and ORAC assays. Journal of Agricultural and Food Chemistry, 57(5), 1768-1774.

Fatemeh, S. R., Saifullah, R., Abbas, F. M. A., \& Azhar, M. E. (2012). Total phenolics, flavonoids and antioxidant activity of banana pulp and peel flours: influence of variety and stage of ripeness. International Food Research Journal, 19(3), 1041-1046.

Finley, J., \& Given, P. (1986). Technological necessity of antioxidants in the food industry. Food and Chemical Toxicology, 24(10-11), 999-1006.

Genskowsky, E., Puente, L., Pérez-Âlvarez, J., Fernandez-Lopez, J., Muñoz, L., \& ViudaMartos, M. (2015). Assessment of antibacterial and antioxidant properties of chitosan edible films incorporated with maqui berry (Aristotelia chilensis). LWT-Food Science and Technology, 64(2), 1057-1062.

Gómez-Guillén, M. C., Ihl, M., Bifani, V., Silva, A., \& Montero, P. (2007). Edible films made from tuna-fish gelatin with antioxidant extracts of two different murta ecotypes leaves (Ugni molinae Turcz). Food Hydrocolloids, 21(7), 1133-1143.

Gutiérrez, L., Sánchez, C., Batlle, R., \& Nerín, C. (2009). New antimicrobial active package for bakery products. Trends in Food Science \& Technology, 20(2), 92-99.

Jouki, M., Yazdi, F. T., Mortazavi, S. A., \& Koocheki, A. (2014). Quince seed mucilage films incorporated with oregano essential oil: physical, thermal, barrier, antioxidant and antibacterial properties. Food Hydrocolloids, 36, 9-19.

Kanazawa, K., \& Sakakibara, H. (2000). High content of dopamine, a strong antioxidant, in Cavendish banana. Journal of Agricultural and Food Chemistry, 48(3), 844-848.

Kanmani, P., \& Rhim, J.-W. (2014). Development and characterization of carrageenan/grapefruit seed extract composite films for active packaging. International Journal of Biological Macromolecules, 68, 258-266.

Komes, D., Horžić, D., Belščak, A., Ganić, K. K., \& Vulić, I. (2010). Green tea preparation and its influence on the content of bioactive compounds. Food Research International, 43(1), 167-176.

Li, J.-H., Miao, J., Wu, J.-L., Chen, S.-F., \& Zhang, Q.-Q. (2014). Preparation and characterization of active gelatin-based films incorporated with natural antioxidants. Food Hydrocolloids, 37, 166-173.

Mayachiew, P., \& Devahastin, S. (2010). Effects of drying methods and conditions on release characteristics of edible chitosan films enriched with Indian gooseberry extract. Food Chemistry, 118(3), 594-601.

Miller, K., \& Krochta, J. (1997). Oxygen and aroma barrier properties of edible films: A review. Trends in Food Science \& Technology, 8(7), 228-237.

Moradi, M., Tajik, H., Rohani, S. M. R., Oromiehie, A. R., Malekinejad, H., Aliakbarlu, J., et al. (2012). Characterization of antioxidant chitosan film incorporated with Zataria multiflora Boiss essential oil and grape seed extract. LWT-Food Science and Technology, 46(2), 477-484.

Moreno, O., Atarés, L., \& Chiralt, A. (2015). Effect of the incorporation of antimicrobial/antioxidant proteins on the properties of potato starch films. Carbohydrate Polymers, 133, 353-364. 
Munro, I. A., \& Garg, M. L. (2008). Nutrient composition and health beneficial effects of macadamia nuts. In Tree Nuts. Boca Raton, FL, USA: CRC Press.

Nguyen, T. B. T., Ketsa, S., \& van Doorn, W. G. (2003). Relationship between browning and the activities of polyphenoloxidase and phenylalanine ammonia lyase in banana peel during low temperature storage. Postharvest Biology and Technology, 30(2), 187-193.

Nie, X., Gong, Y., Wang, N., \& Meng, X. (2015). Preparation and characterization of edible myofibrillar protein-based film incorporated with grape seed procyanidins and green tea polyphenol. LWT-Food Science and Technology, 64(2), 1042-1046.

Pan, Y., Wang, K., Huang, S., Wang, H., Mu, X., He, C., et al. (2008). Antioxidant activity of microwave-assisted extract of longan (Dimocarpus Longan Lour.) peel. Food Chemistry, 106(3), 1264-1270.

Papoutsis, K., Pristijono, P., Golding, J. B., Stathopoulos, C. E., Bowyer, M. C., Scarlett, C. J., et al. (2016). Optimisation of aqueous extraction conditions for the recovery of phenolic compounds and antioxidants from lemon pomace. International Journal of Food Science and Technology, 51(9), 2009-2018.

Park, J. W., Im, S. S., Kim, S. H., \& Kim, Y. H. (2000). Biodegradable polymer blends of poly(L-lactic acid) and gelatinized starch. Polymer Engineering and Science, 40(12), 2539-2550.

Perazzo, K. K. N. C. L., Conceição, A. C. d. V., dos Santos, J. C. P., Assis, D. d. J., Souza, C. O., \& Druzian, J. I. (2014). Properties and antioxidant action of actives cassava starch films incorporated with green tea and palm oil extracts. PloS one, 9(9), e105199.

Pérez-Jiménez, J., Arranz, S., Tabernero, M., Díaz-Rubio, M. E., Serrano, J., Goñi, I., et al. (2008). Updated methodology to determine antioxidant capacity in plant foods, oils and beverages: Extraction, measurement and expression of results. Food Research International, 41(3), 274-285.

Ramos, Ó. L., Santos, A. C., Leão, M. V., Pereira, J. O., Silva, S. I., Fernandes, J. C., et al. (2012). Antimicrobial activity of edible coatings prepared from whey protein isolate and formulated with various antimicrobial agents. International Dairy Journal, 25(2), $132-141$.

Rickard, S. (2011). The new ornamental garden. Collingwood VIC, Australia: CSIRO Publishing.

Roginsky, V., \& Lissi, E. A. (2005). Review of methods to determine chain-breaking antioxidant activity in food. Food Chemistry, 92(2), 235-254.

Rotta, J., Ozório, R. Á., Kehrwald, A. M., de Oliveira Barra, G. M., Amboni, R. D. d. M. C., \& Barreto, P. L. M. (2009). Parameters of color, transparency, water solubility, wettability and surface free energy of chitosan/hydroxypropylmethylcellulose (HPMC) films plasticized with sorbitol. Materials Science and Engineering C, 29(2), 619-623.

Rubilar, J. F., Cruz, R. M., Silva, H. D., Vicente, A. A., Khmelinskii, I., \& Vieira, M. C. (2013). Physico-mechanical properties of chitosan films with carvacrol and grape seed extract. Journal of Food Engineering, 115(4), 466-474.

Saberi, B., Chockchaisawasdee, S., Golding, J. B., Scarlett, C. J., \& Stathopoulos, C. E. (2017). Characterization of pea starch-guar gum biocomposite edible films enriched by natural antimicrobial agents for active food packaging. Food and Bioproducts Processing, 105, 51-63.

Saberi, B., Thakur, R., Bhuyan, D. J., Vuong, Q. V., Chockchaisawasdee, S., Golding, J. B., et al. (2016a). Development of edible blend films with good mechanical and barrier properties from pea starch and guar gum. Starch - Stärke, 69(1-2), 1-16.

Saberi, B., Thakur, R., Vuong, Q. V., Chockchaisawasdee, S., Golding, J. B., Scarlett, C. J., et al. (2016b). Optimization of physical and optical properties of biodegradable edible films based on pea starch and guar gum. Industrial Crops and Products, 86, 342-352. 
Saberi, B., Vuong, Q. V., Chockchaisawasdee, S., Golding, J. B., Scarlett, C. J., \& Stathopoulos, C. E. (2016c). Mechanical and physical properties of pea starch edible films in the presence of glycerol. Journal of Food Processing and Preservation, 40(6), 1339-1351.

Siripatrawan, U., \& Harte, B. R. (2010). Physical properties and antioxidant activity of an active film from chitosan incorporated with green tea extract. Food Hydrocolloids, 24(8), 770-775.

Sivarooban, T., Hettiarachchy, N., \& Johnson, M. (2008). Physical and antimicrobial properties of grape seed extract, nisin, and EDTA incorporated soy protein edible films. Food Research International, 41(8), 781-785.

Someya, S., Yoshiki, Y., \& Okubo, K. (2002). Antioxidant compounds from bananas (Musa Cavendish). Food Chemistry, 79(3), 351-354.

Steinmann, J., Buer, J., Pietschmann, T., \& Steinmann, E. (2013). Anti- infective properties of epigallocatechin- 3- gallate (EGCG), a component of green tea. British Journal of Pharmacology, 168(5), 1059-1073.

Sun, X., Wang, Z., Kadouh, H., \& Zhou, K. (2014). The antimicrobial, mechanical, physical and structural properties of chitosan-gallic acid films. LWT-Food Science and Technology, 57(1), 83-89.

Talja, R. A., Helén, H., Roos, Y. H., \& Jouppila, K. (2007). Effect of various polyols and polyol contents on physical and mechanical properties of potato starch-based films. Carbohydrate Polymers, 67(3), 288-295.

Thakur, R., Saberi, B., Pristijono, P., Golding, J., Stathopoulos, C., Scarlett, C., et al. (2016). Characterization of rice starch- 1-carrageenan biodegradable edible film. Effect of stearic acid on the film properties. International Journal of Biological Macromolecules.

Tongdeesoontorn, W., Mauer, L. J., Wongruong, S., Sriburi, P., \& Rachtanapun, P. (2011). Effect of carboxymethyl cellulose concentration on physical properties of biodegradable cassava starch-based films. Chemistry Central journal, 5(1), 6.

van den Berg, H., Faulks, R., Granado, H. F., Hirschberg, J., Olmedilla, B., Sandmann, G., et al. (2000). The potential for the improvement of carotenoid levels in foods and the likely systemic effects. Journal of the Science of Food and Agriculture, 80(7), 880-912.

Vermeiren, L., Devlieghere, F., van Beest, M., de Kruijf, N., \& Debevere, J. (1999). Developments in the active packaging of foods. Trends in Food Science \& Technology, 10(3), 77-86.

Viuda-Martos, M., Ruiz-Navajas, Y., Fernández-López, J., Sendra, E., Sayas-Barberá, E., \& Pérez-Álvarez, J. A. (2011). Antioxidant properties of pomegranate (Punica granatum L.) bagasses obtained as co-product in the juice extraction. Food Research International, 44(5), 1217-1223.

Vodnar, D. C. (2012). Inhibition of Listeria monocytogenes ATCC 19115 on ham steak by tea bioactive compounds incorporated into chitosan-coated plastic films. Chemistry Central journal, 6(1), 74.

Vu, H. T., Scarlett, C. J., \& Vuong, Q. V. (2016). Optimization of ultrasound-assisted extraction conditions for recovery of phenolic compounds and antioxidant capacity from banana (Musa cavendish) peel. Journal of Food Processing and Preservation, In press.

Vuong, Q. V., Hirun, S., Phillips, P. A., Chuen, T. L., Bowyer, M. C., Goldsmith, C. D., et al. (2014). Fruit-derived phenolic compounds and pancreatic cancer: perspectives from Australian native fruits. Journal of Ethnopharmacology, 152(2), 227-242.

Wang, L., Dong, Y., Men, H., Tong, J., \& Zhou, J. (2013). Preparation and characterization of active films based on chitosan incorporated tea polyphenols. Food Hydrocolloids, 32(1), 35-41. 
Wang, L., Wang, Q., Tong, J., \& Zhou, J. (2015a). Physicochemical properties of chitosan films incorporated with honeysuckle flower extract for active food packaging. Journal of Food Process Engineering, 40(1).

Wang, Q., Tian, F., Feng, Z., Fan, X., Pan, Z., \& Zhou, J. (2015b). Antioxidant activity and physicochemical properties of chitosan films incorporated with Lycium barbarum fruit extract for active food packaging. International Journal of Food Science \& Technology, $50(2), 458-464$.

Wang, S., Marcone, M., Barbut, S., \& Lim, L. T. (2012). The impact of anthocyanin- rich red raspberry extract (ARRE) on the properties of edible soy protein isolate (SPI) films. Journal of Food Science, 77(4), C497-C505.

Wu, J., Chen, S., Ge, S., Miao, J., Li, J., \& Zhang, Q. (2013). Preparation, properties and antioxidant activity of an active film from silver carp (Hypophthalmichthys molitrix) skin gelatin incorporated with green tea extract. Food Hydrocolloids, 32(1), 42-51.

Xu, Y., Kim, K. M., Hanna, M. A., \& Nag, D. (2005). Chitosan-starch composite film: preparation and characterization. Industrial Crops and Products, 21(2), 185-192.

Yu, S.-H., Tsai, M.-L., Lin, B.-X., Lin, C.-W., \& Mi, F.-L. (2015). Tea catechins-cross-linked methylcellulose active films for inhibition of light irradiation and lipid peroxidation induced $\beta$-carotene degradation. Food Hydrocolloids, 44, 491-505.

Zhang, Y., \& Han, J. H. (2006). Plasticization of pea starch films with monosaccharides and polyols. Journal of Food Science, 71(6), E253-E261.

Zhishen, J., Mengcheng, T., \& Jianming, W. (1999). The determination of flavonoid contents in mulberry and their scavenging effects on superoxide radicals. Food Chemistry, 64(4), 555-559.

\section{Figure captions}

Fig. 1 FTIR spectra of PSGG films containing different natural antioxidant compounds at 3 $\mathrm{mg} / \mathrm{mL}$ in the region $400-4000 \mathrm{~cm}^{-1}$.

Fig. 2 Total phenol contents (A) and total flavonoid (B) of PSGG films formulated with different natural compounds at different concentrations. 
656

657 
1 Table 1 Moisture content (MC), water solubility (WS), gel fraction (GF), swelling degree (SD), and water vapour permeability (WVP) of edible

2 PSGG films as a function of natural compound concentrations.

\begin{tabular}{|c|c|c|c|c|c|}
\hline $\begin{array}{c}\text { Natural compounds } \\
\text { concentration }(\mathrm{mg} / \mathrm{mL})\end{array}$ & $\begin{array}{l}\mathrm{MC} \\
(\%)\end{array}$ & $\begin{array}{l}\text { WS } \\
(\%)\end{array}$ & $\begin{array}{l}\mathrm{GF} \\
(\%)\end{array}$ & SD & $\begin{array}{c}\text { WVP } \\
\left(\times 10^{-10} \mathrm{gs}^{-1} \mathrm{~m}^{-1} \mathrm{~Pa}^{-1}\right)\end{array}$ \\
\hline PSGG $^{\text {** }}$ & $20.13 \pm 1.48^{\mathrm{cd}}$ & $27.67 \pm 2.72^{\mathrm{a}}$ & $15.87 \pm 2.75^{\mathrm{m}}$ & $56.85 \pm 5.50^{\mathrm{a}}$ & $13.87 \pm 1.11^{\mathrm{bc}}$ \\
\hline 0.75 & $20.29 \pm 2.02^{\mathrm{c}}$ & $25.71 \pm 2.02^{\mathrm{ab}}$ & $38.96 \pm 8.33^{\text {ghi }}$ & $45.63 \pm 3.03^{b c}$ & $13.16 \pm 0.75^{\mathrm{cd}}$ \\
\hline 1.5 & $25.63 \pm 1.59^{\mathrm{a}}$ & $23.56 \pm 1.59^{\mathrm{bcd}}$ & $55.63 \pm 9.39^{\mathrm{def}}$ & $52.29 \pm 6.05^{\mathrm{ab}}$ & $16.49 \pm 1.02^{\mathrm{a}}$ \\
\hline 2.25 & $18.83 \pm 0.52^{\text {cdef }}$ & $22.18 \pm 0.52^{\text {cde }}$ & $67.29 \pm 4.33^{\mathrm{ab}}$ & $32.83 \pm 3.77^{\mathrm{de}}$ & $12.59 \pm 1.25^{\mathrm{cde}}$ \\
\hline 3 & $17.49 \pm 0.76^{\text {efg }}$ & $20.31 \pm 0.76^{\mathrm{efg}}$ & $76.71 \pm 5.74^{\mathrm{a}}$ & $25.83 \pm 3.28^{\text {efg }}$ & $10.20 \pm 0.99^{\mathrm{fg}}$ \\
\hline 0.75 & $19.33 \pm 0.95^{\mathrm{cde}}$ & $24.58 \pm 0.95^{b c}$ & $29.96 \pm 1.53^{\mathrm{ijk}}$ & $40.83 \pm 4.87^{\mathrm{c}}$ & $12.83 \pm 0.85^{\mathrm{cd}}$ \\
\hline 1.5 & $22.75 \pm 2.71^{b}$ & $21.23 \pm 2.71^{\text {def }}$ & $42.29 \pm 3.95^{\mathrm{fgh}}$ & $45.96 \pm 4.57^{b c}$ & $14.99 \pm 2.08^{\mathrm{ab}}$ \\
\hline 2.25 & $17.78 \pm 1.89^{\operatorname{defg}}$ & $19.18 \pm 1.89^{\mathrm{fgh}}$ & $58.29 \pm 8.07^{\text {bcd }}$ & $27.74 \pm 4.76^{\mathrm{def}}$ & $11.41 \pm 0.66^{\mathrm{def}}$ \\
\hline 3 & $16.49 \pm 1.05^{\text {fghi }}$ & $17.64 \pm 1.05^{\mathrm{hi}}$ & $64.38 \pm 8.51^{\mathrm{bc}}$ & $21.16 \pm 1.59^{\text {fghi }}$ & $9.32 \pm 0.57^{\text {gh }}$ \\
\hline 0.75 & $15.62 \pm 0.74^{\text {ghij }}$ & $21.72 \pm 0.74^{\text {def }}$ & $21.16 \pm 2.49^{\mathrm{klm}}$ & $33.23 \pm 6.23^{d}$ & $10.89 \pm 0.33^{\mathrm{efg}}$ \\
\hline 1.5 & $14.90 \pm 1.26^{\mathrm{hij}}$ & $20.23 \pm 1.26^{\mathrm{efgh}}$ & $33.02 \pm 5.39^{\mathrm{hij}}$ & $26.56 \pm 2.60^{\operatorname{defg}}$ & $9.71 \pm 0.64^{\mathrm{fgh}}$ \\
\hline 2.25 & $13.49 \pm 0.90^{\mathrm{jk}}$ & $17.64 \pm 0.90^{\mathrm{hi}}$ & $45.06 \pm 7.62^{\mathrm{efg}}$ & $19.56 \pm 3.74^{\text {ghi }}$ & $7.53 \pm 0.51^{\mathrm{i}}$ \\
\hline 3 & $11.16 \pm 0.75^{\mathrm{k}}$ & $15.11 \pm 0.75^{\mathrm{i}}$ & $51.05 \pm 7.65^{\mathrm{def}}$ & $14.56 \pm 1.29^{\mathrm{ij}}$ & $7.05 \pm 0.80^{\mathrm{i}}$ \\
\hline 0.75 & $17.29 \pm 0.95^{\mathrm{efgh}}$ & $22.25 \pm 0.95^{\mathrm{cde}}$ & $17.83 \pm 4.65^{\mathrm{lm}}$ & $29.83 \pm 2.71^{\mathrm{de}}$ & $11.49 \pm 0.72^{\text {def }}$ \\
\hline 1.5 & $15.90 \pm 0.43^{\text {ghij }}$ & $20.89 \pm 0.43^{\text {efg }}$ & $27.69 \pm 2.89^{\mathrm{jkl}}$ & $22.19 \pm 1.86^{\mathrm{fgh}}$ & $10.16 \pm 1.04^{\mathrm{fg}}$ \\
\hline 2.25 & $14.57 \pm 0.80^{\mathrm{ij}}$ & $18.52 \pm 0.80^{\mathrm{gh}}$ & $39.63 \pm 3.03^{\text {ghi }}$ & $17.89 \pm 3.05^{\mathrm{hij}}$ & $8.19 \pm 0.92^{\mathrm{hi}}$ \\
\hline 3 & $13.49 \pm 1.90^{\mathrm{jk}}$ & $15.97 \pm 1.90^{\mathrm{i}}$ & $46.88 \pm 5.38^{\text {efg }}$ & $12.56 \pm 0.76^{\mathrm{j}}$ & $7.39 \pm 1.27^{\mathrm{i}}$ \\
\hline
\end{tabular}

${ }^{*}$ Values are the means of triplicates \pm standard deviations. Means at same column with different lower case are significantly different $(P<0.05)$.

** Please refer to Saberi et al. (2016b) and Saberi et al. (2016a). 
1 Table 2 Optical properties of edible PSGG films as a function of natural compound concentrations.

\begin{tabular}{|c|c|c|c|c|c|}
\hline $\begin{array}{l}\text { Natural compounds } \\
\text { concentration }(\mathrm{mg} / \mathrm{mL})\end{array}$ & $L$ & $a$ & $b$ & $\Delta \mathrm{E}$ & $\begin{array}{c}\text { Transparency } \\
(\%)\end{array}$ \\
\hline PSGG $^{* * *}$ & $93.84 \pm 2.48^{\mathrm{a}}$ & $-3.54 \pm 0.52^{\mathrm{e}}$ & $6.24 \pm 0.70^{\text {efg }}$ & $4.54 \pm 0.51^{\mathrm{i}}$ & $82.27 \pm 4.67^{\mathrm{a}}$ \\
\hline 0.75 & $91.71 \pm 0.64^{b c}$ & $-2.04 \pm 0.27^{\mathrm{d}}$ & $6.38 \pm 0.37^{\mathrm{ef}}$ & $5.53 \pm 0.38^{\mathrm{hi}}$ & $82.11 \pm 0.78^{a}$ \\
\hline 1.5 & $90.85 \pm 0.80^{\mathrm{bcd}}$ & $-1.01 \pm 0.95^{\mathrm{c}}$ & $6.04 \pm 0.73^{\text {efg }}$ & $6.70 \pm 0.69^{\text {fgh }}$ & $81.54 \pm 0.77^{\mathrm{ab}}$ \\
\hline 2.25 & $89.63 \pm 0.76^{\text {cdef }}$ & $1.04 \pm 0.89^{b}$ & $5.58 \pm 0.70^{\mathrm{fgh}}$ & $8.07 \pm 0.78^{\mathrm{def}}$ & $79.54 \pm 0.91^{\mathrm{abcd}}$ \\
\hline 3 & $87.65 \pm 0.77^{\text {fghi }}$ & $2.52 \pm 0.23^{\mathrm{a}}$ & $4.91 \pm 0.49^{\mathrm{h}}$ & $10.41 \pm 1.13^{b c}$ & $78.21 \pm 1.75^{\mathrm{cde}}$ \\
\hline 0.75 & $92.04 \pm 0.27^{\mathrm{ab}}$ & $-2.38 \pm 0.37^{\mathrm{d}}$ & $6.51 \pm 0.23^{\mathrm{def}}$ & $5.80 \pm 0.65^{\mathrm{ghi}}$ & $82.04 \pm 0.89^{\mathrm{a}}$ \\
\hline 1.5 & $91.18 \pm 0.77^{b c}$ & $-1.71 \pm 0.64^{\mathrm{cd}}$ & $6.18 \pm 0.67^{\mathrm{efg}}$ & $6.77 \pm 0.72^{\text {efgh }}$ & $81.11 \pm 0.38^{\mathrm{ab}}$ \\
\hline 2.25 & $90.67 \pm 0.46^{\mathrm{bcd}}$ & $0.98 \pm 0.21^{\mathrm{b}}$ & $5.84 \pm 0.44^{\text {efgh }}$ & $8.89 \pm 0.72^{\mathrm{d}}$ & $80.21 \pm 1.92^{\mathrm{abc}}$ \\
\hline 3 & $88.83 \pm 1.23^{\mathrm{defg}}$ & $1.44 \pm 0.54^{\mathrm{b}}$ & $5.18 \pm 1.00^{\mathrm{gh}}$ & $10.88 \pm 0.58^{\mathrm{abc}}$ & $79.21 \pm 0.78^{\mathrm{bcd}}$ \\
\hline 0.75 & $90.51 \pm 0.59^{\mathrm{bcd}}$ & $-3.76 \pm 0.39^{\mathrm{e}}$ & $7.51 \pm 0.61^{\mathrm{cd}}$ & $7.12 \pm 0.56^{\mathrm{efgh}}$ & $81.38 \pm 0.37^{\mathrm{ab}}$ \\
\hline 1.5 & $89.62 \pm 0.64^{\text {cdef }}$ & $-4.00 \pm 0.66^{\mathrm{ef}}$ & $8.49 \pm 0.47^{b c}$ & $8.31 \pm 0.58^{\mathrm{de}}$ & $80.05 \pm 0.12^{\mathrm{abc}}$ \\
\hline 2.25 & $87.03 \pm 1.51^{\text {ghi }}$ & $-4.33 \pm 0.29^{\mathrm{ef}}$ & $9.50 \pm 0.56^{\mathrm{ab}}$ & $11.10 \pm 1.31^{\mathrm{ab}}$ & $76.40 \pm 1.00^{\mathrm{e}}$ \\
\hline 3 & $86.05 \pm 0.45^{\mathrm{i}}$ & $-4.82 \pm 0.50^{f}$ & $10.17 \pm 0.68^{\mathrm{a}}$ & $12.29 \pm 0.67^{\mathrm{a}}$ & $73.83 \pm 1.49^{\mathrm{f}}$ \\
\hline 0.75 & $91.04 \pm 0.73^{b c}$ & $-3.70 \pm 0.33^{\mathrm{e}}$ & $6.94 \pm 0.13^{\mathrm{de}}$ & $6.44 \pm 0.67^{\mathrm{gh}}$ & $81.58 \pm 0.23^{\mathrm{ab}}$ \\
\hline 1.5 & $90.28 \pm 0.80^{\text {bcde }}$ & $-3.90 \pm 0.04^{\mathrm{ef}}$ & $7.52 \pm 0.48^{\mathrm{cd}}$ & $7.33 \pm 0.83^{\text {efg }}$ & $80.57 \pm 0.70^{\mathrm{abc}}$ \\
\hline 2.25 & $88.30 \pm 1.94^{\mathrm{efgh}}$ & $-4.10 \pm 0.31^{\mathrm{ef}}$ & $8.06 \pm 0.39^{c}$ & $9.41 \pm 1.79^{\mathrm{cd}}$ & $77.06 \pm 1.62^{\mathrm{de}}$ \\
\hline 3 & $86.72 \pm 1.02^{\mathrm{hi}}$ & $-4.32 \pm 0.35^{\mathrm{ef}}$ & $9.32 \pm 0.75^{\mathrm{ab}}$ & $11.34 \pm 0.72^{\mathrm{ab}}$ & $75.72 \pm 0.53^{\mathrm{ef}}$ \\
\hline
\end{tabular}

$2{ }^{*}$ Values are the means of triplicates \pm standard deviations. Means at same column with different lower case are significantly different $(P<0.05)$.

** Please refer to Saberi et al. (2016b) and Saberi et al. (2016a). 


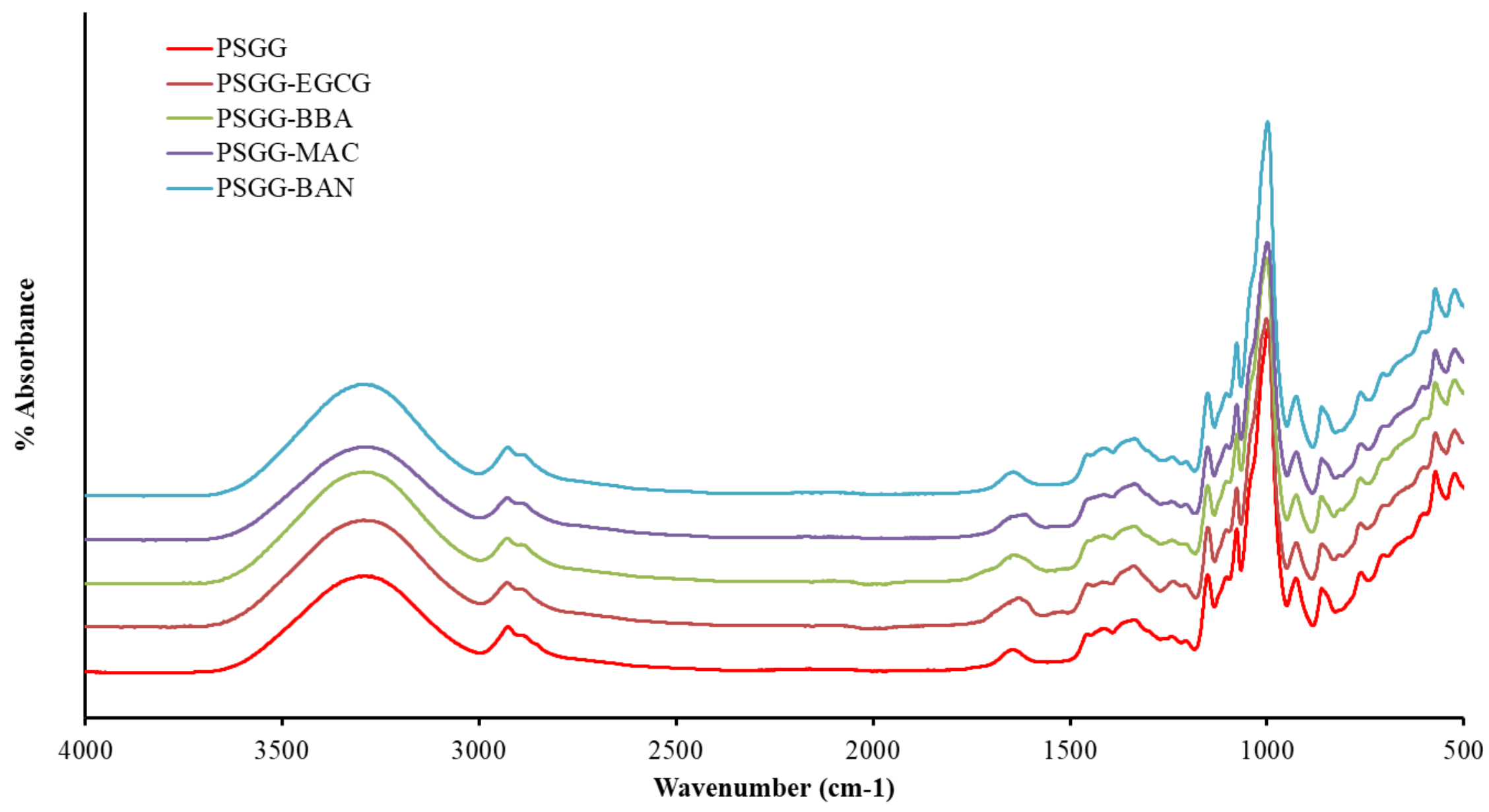

2 Fig. 1 FTIR spectra of PSGG films containing different natural antioxidant compounds at $3 \mathrm{mg} / \mathrm{mL}$ in the region $400-4000 \mathrm{~cm}^{-1}$. 


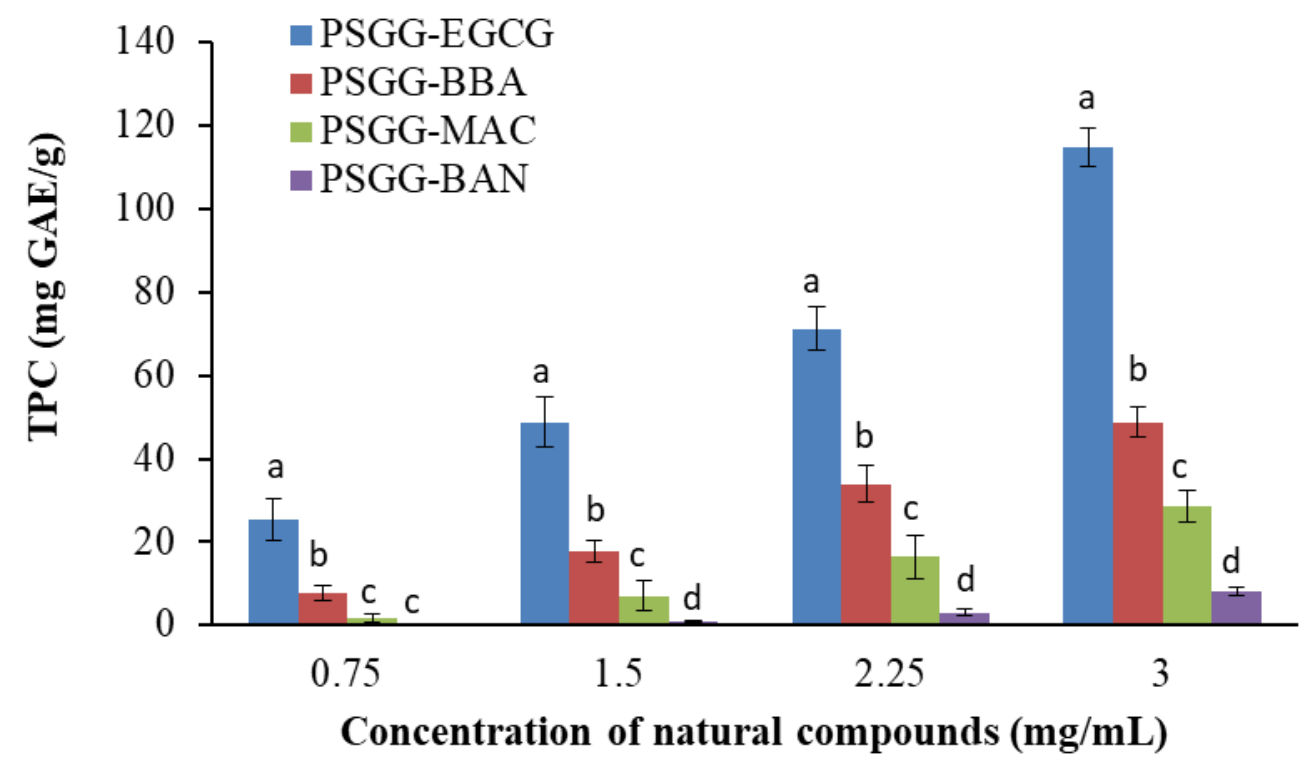

A

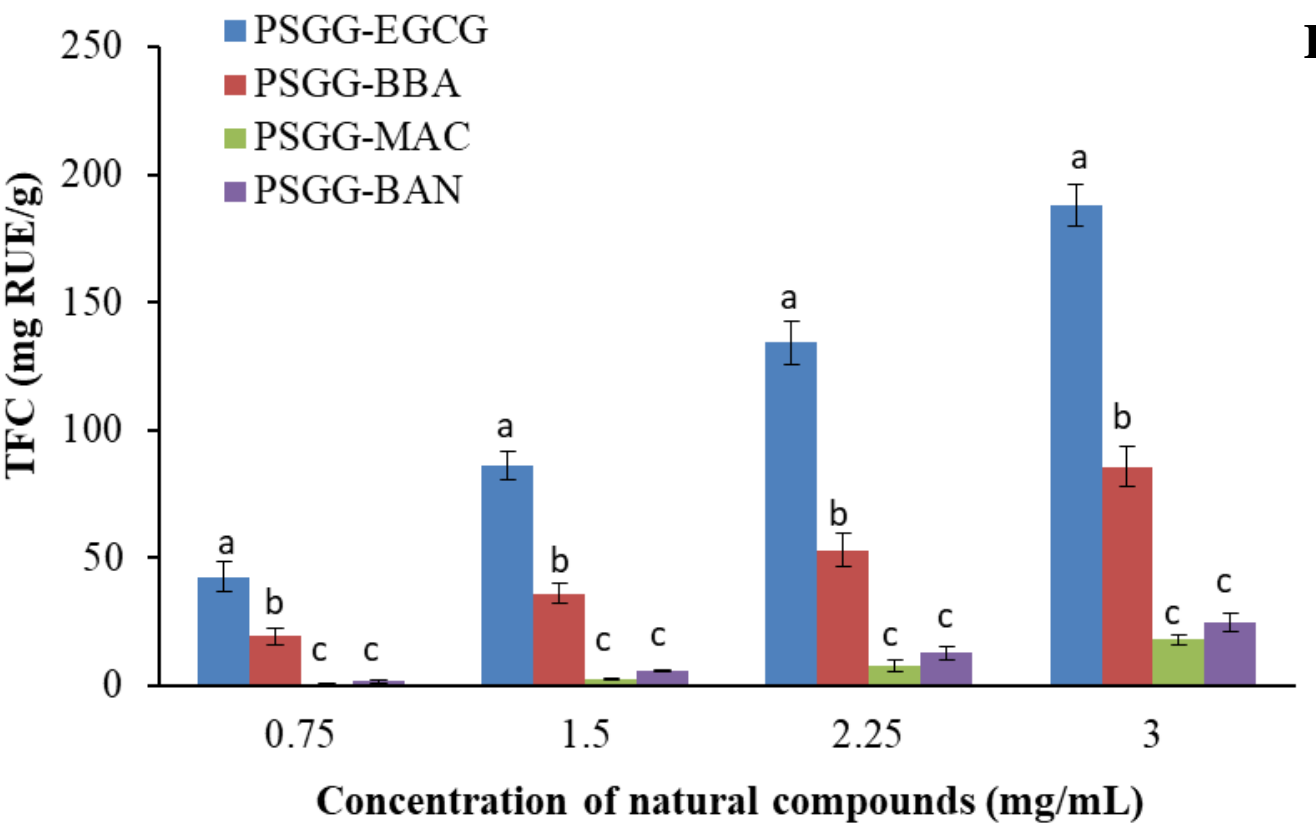

1 Fig. 2 Total phenol content (A) and total flavonoid content (B) of PSGG films formulated with

2 different natural compounds at different concentrations.

3 
1 Table 3 Antioxidant effect of PSGG edible films incorporated with natural compounds at

2 different concentrations by means of three different antioxidant tests such as DPPH, CUPRAC,

3 and FRAPS assays.

\begin{tabular}{cccc}
\hline $\begin{array}{c}\text { Natural compounds } \\
\text { concentration }(\mathrm{mg} / \mathrm{mL})\end{array}$ & $\begin{array}{c}\text { DPPH } \\
(\mathrm{mg} \mathrm{TE} / \mathrm{g})\end{array}$ & $\begin{array}{c}\text { CUPRAC } \\
(\mathrm{mg} \mathrm{TE} / \mathrm{g})\end{array}$ & $\begin{array}{c}\text { FRAP } \\
(\mathrm{mg} \mathrm{TE} / \mathrm{g})\end{array}$ \\
\hline 0.75 & $4.34 \pm 0.70^{\text {efgh }}$ & $2.62 \pm 0.55^{\text {def }}$ & $9.08 \pm 0.83^{\text {de }}$ \\
1.5 & $8.95 \pm 2.46^{\text {cd }}$ & $8.74 \pm 1.52^{\mathrm{c}}$ & $16.23 \pm 2.19^{\mathrm{c}}$ \\
2.25 & $19.83 \pm 3.18^{\mathrm{b}}$ & $17.95 \pm 2.08^{\mathrm{b}}$ & $27.11 \pm 5.86^{\mathrm{b}}$ \\
3 & $39.78 \pm 3.16^{\mathrm{a}}$ & $29.78 \pm 3.16^{\mathrm{a}}$ & $59.78 \pm 7.02^{\mathrm{a}}$ \\
\hline 0.75 & $1.23 \pm 0.48^{\mathrm{hi}}$ & $0.95 \pm 0.27^{\text {efg }}$ & $0.88 \pm 0.16^{\text {gh }}$ \\
1.5 & $5.36 \pm 1.35^{\text {ef }}$ & $3.35 \pm 1.10^{\mathrm{d}}$ & $3.78 \pm 0.47^{\text {fgh }}$ \\
2.25 & $12.03 \pm 2.44^{\mathrm{c}}$ & $7.68 \pm 1.63^{\mathrm{c}}$ & $10.45 \pm 1.06^{\mathrm{d}}$ \\
3 & $19.75 \pm 2.80^{\mathrm{b}}$ & $17.11 \pm 1.08^{\mathrm{b}}$ & $16.64 \pm 1.48^{\mathrm{c}}$ \\
\hline 0.75 & $0.47 \pm 0.09^{\mathrm{i}}$ & $0.13 \pm 0.10^{\mathrm{g}}$ & $0.13 \pm 0.10^{\mathrm{h}}$ \\
1.5 & $1.51 \pm 0.73^{\mathrm{ghi}}$ & $0.85 \pm 0.34^{\text {efg }}$ & $0.60 \pm 0.34^{\text {gh }}$ \\
2.25 & $4.54 \pm 0.73^{\text {efg }}$ & $3.35 \pm 0.87^{\mathrm{d}}$ & $2.83 \pm 0.54^{\text {fgh }}$ \\
3 & $10.21 \pm 2.24^{\mathrm{c}}$ & $8.68 \pm 1.55^{\mathrm{c}}$ & $6.74 \pm 1.35^{\text {def }}$ \\
\hline 0.75 & $0.17 \pm 0.09^{\mathrm{i}}$ & $0.06 \pm 0.0326^{\mathrm{g}}$ & $0.02 \pm 0.01^{\mathrm{h}}$ \\
1.5 & $0.69 \pm 0.13^{\mathrm{i}}$ & $0.48 \pm 0.06^{\mathrm{fg}}$ & $0.37 \pm 0.26^{\mathrm{gh}}$ \\
2.25 & $2.90 \pm 0.82^{\text {fghi }}$ & $3.02 \pm 0.68^{\mathrm{de}}$ & $1.50 \pm 0.17^{\text {gh }}$ \\
3 & $6.23 \pm 1.37^{\text {de }}$ & $7.35 \pm 1.09^{\mathrm{c}}$ & $4.84 \pm 0.71^{\text {efg }}$ \\
\hline
\end{tabular}

4

5

6

7

8

9

10

11

12

6

${ }^{*}$ Values are the means of triplicates \pm standard deviations. Means at same column with different lower case are significantly different $(P<0.05)$. 
2 Table 4 Correlation between phytochemicals and antioxidant properties of films containing

3 natural compounds.

\begin{tabular}{rccc}
\hline $\begin{array}{c}\text { Films with } \\
\text { natural compounds }\end{array}$ & DPPH & CUPRAC & FRAP \\
\hline TPC & 0.981 & 0.993 & 0.967 \\
TFC & 0.945 & 0.991 & 0.909 \\
\hline TPC & 0.997 & 0.944 & 0.996 \\
TFC & 0.993 & 0.940 & 0.986 \\
\hline TPC & 0.979 & 0.965 & 0.972 \\
TFC & 0.950 & 0.998 & 0.997 \\
\hline TPC & 0.993 & 0.997 & 0.996 \\
TFC & 0.992 & 0.985 & 0.965 \\
\hline
\end{tabular}

4

5

6

7

8

9

10

11

12

13 